\title{
REALIZATION OF INTEGRATED LEARNING IN STUDY PRACTICE: PRE-SERVICE TEACHERS EXPERIENCES
}

\author{
Ilze Briška \\ University of Latvia, Latvia \\ Gunta Siliṇa-Jasjukeviča \\ University of Latvia, Latvia
}

\begin{abstract}
The integrated teaching is important tool for promoting the development of students' critical and creative thinking, self-cognition, learning and cooperation skills and cultural understanding in a constantly changing world. In Latvia, integrated curriculum has become a challenge for educational reforms, too. Latvian teacher educators are looking for appropriate Curriculum content and strategies, in order to promote pre-service teachers with understanding of integrated learning, courage and ability to implement them in professional activities.

The aim of an article is analyze possibilities how to improve the pre-service teachers' readiness to plan integrated lessons for study practice.

Methods: qualitative analysis of students' pedagogical practice diaries.

In conclusions and discussion, the suggestions for the development of teacher education Curriculum towards strengthening the different approaches to integrated learning in school education.
\end{abstract}

Keywords: integrated education in primary school, pedagogical practice, teacher education, modalities of integrated learning.

\section{Introduction}

The integrated curriculum teaching is important tool for promoting the development of school students' knowledge, skills and attitudes that suits him in solving problems in a changing reallife situation - self-cognition, critical and creative thinking, learning and cooperation skills with others and cultural understanding in a constantly changing world. In Latvia integrated curriculum has actualized in educational reforms.

An important resource for improving the professional skills of pre-service teachers is the pedagogical practice. Learning how to plan the lessons is a key skill that the students have to develop in the study process. "Planning as a complex process, and performance indicators that seem to present planning as an important 
but still straight forward professional skill to be acquired." (Muttona, Haggera, \& Burn, 2011)

The aim of an article is analyze possibilities how to improve the pre-service teachers' readiness to plan and realize integrated lessons in study practice and.

Methods: The study was based on the qualitative design. A content analysis of materials from 10 pre-service teachers' pedagogical practice diaries were proceeded in order to identify appearance of different kinds of integration there, interpret the problematic issues and summarize suggestions for the development of study practice instruction.

\section{Theoretical background}

The integrated approach to learning is in focus of pre-school and primary educators over several decades. In Latvia, idea of integrated learning was developed by Petersons (Pētersons, 1931) and Dekens (Dēķens, 1919); more recently, it is explored and developed by Petere (Petere, 2014) and Anspoka (Anspoka, 2003). On general, a term 'integrated learning' is used by meaning: learning more than one subject at once and building holistic system (be either organic, not mechanic). As the most essential characteristic of integrated teaching/learning is the wholeness (Kaulina, 2013; Petere, 2014). Together with the acquisition of learning content, 'a holistic approach to personality development promotes a learning according to learners individual abilities, learner's intellectual, emotional and social development within correlations' (Anspoka, 2003: 5), awareness of the motive in integrated learning as the inner driving force, a subjective component, individual and different to everyone (Petere, 2014: 116). Thus, a teacher's action is important, as a result of which, the conditions are created where a learner him/herself sees the wholeness of learning content, not the teacher indicates the connections to be seen. The efficiency of integrated teaching/learning is justified with the connection of learning to life (because life is a whole), gaining the unity of a child's spiritual development and understanding of coherence within knowledge. It demands for teacher's ability to organize her work with a clear conception, structure, methods and principles, combining several educational paradigms (Csorba, 2013).

As educational approach, integrated learning pretends to be more effective than learning each subject separately. The problem is, that integration risks being not effective tool for learning, without appropriate conceptual understanding of the structural components of a wholeness and their interconnections. J Hattie's research approves that idea (Hattie, 2009). One more challenge for teacher educators is that recent students have not rich experiences with integrated learning during their schooling; so, it is a new topic for them, while learning separate subjects is familiar and well-known. 
In recent educational discourse, three approaches to integration are defined: multidisciplinary, interdisciplinary and transdisciplinary (Drake \& Burns, 2004), which can help to understand the usefulness of differently organizedcontent and process of learning for reaching particular educational goals better. Each of them has a different structure of a whole, different focus on educational aims, different connections between curriculum subjects and relations to contexts of real world, life.

Organizing the learning of several disciplines around one theme/ topic, is characteristic for multidisciplinary approachto integration. Itfocuses primarily on the obtaining clear, structured, knowledge and skillsto address key learning standards identified by the area (Steinberg, 1997), as he call it - 'routine expertise'. There, teaching might not differ much from the teaching separate subject.

In interdisciplinary approach to integration, teachers organize the curriculum around learning across disciplines. Learners integrate information, methods, tools, perspectives, possibilities, ideas, concepts and theories from two or more fields in order to create 'products', explain the phenomenon or solve problems. Learners are not able to do it using means of one field such as information, methods, tools, ideas and concepts (Boix-Mansilla, 2010). Interdisciplinary teaching/learning encourageslearners' self-directed and selfdesigned way of mastering learning content (Kidron \& Kali, 2015) within the boundaries of a set cognitive question. The focus of interdisciplinary approach is not on what a learner is learning but how he/she is doing it (Kramer et al., 2007) with a purpose to help them to reachdeeper levels of conceptual coherence, varied set of reasoning and meta cognitive strategies, 'adaptive expertise' (Hatano \& Inagaki, 1986). So, there a teacher must be able to identify learners' abilities and introduce the implementation of different learning strategies.

In the transdisciplinary approach to integration, learners develop life skills as they apply interdisciplinary and disciplinary skills in a real-life context. Learning becomes organic, meaningful and transformative holisticv.s. mechanic (Sterling, 2011). Two routes lead to transdisciplinary integration: project-based learning and negotiating the curriculum (Drake \& Burns 2004). Although content may be grounded in a discipline, the unit is not considered a science unit or social studies unit. It is important in transdisciplinary teaching learning toinvolve students in asking authentic questions - have them participate and connect to their lives as well as to give opportunity for students to discover answers. Therefore, the tasks should be inquiry-based and allow time for discovery - "uncovering" (Kaufman, 2003).

In context of the new demands to education - development of students' competences and life skills - the transdisciplinary approach can be seen as the most productive kind of integration. The task of teacher educators is to set 
appropriate questions for pre-service teachers, in order to encourage them to realize deeper ways of integrated teaching in their study practice.

Transdisciplinary approach does not deny multi- and inter-disciplinary learning, but use their tools as steps in real-life problem-solving process.

For empirical research, the key ideas are summarize in Table 1.

Table 1 Comparison of multidisciplinary, inter-disciplinary and transdisciplinary learning

\begin{tabular}{|l|l|l|l|}
\hline Categories & Multidisciplinary & \multicolumn{1}{|c|}{ Inter-disciplinary } & Trans-disciplinary \\
\hline Focus & Content-oriented & Student - oriented & Problem - oriented \\
\hline $\begin{array}{l}\text { Structure of } \\
\text { a whole }\end{array}$ & $\begin{array}{l}\text { Relating the } \\
\text { concepts and } \\
\text { processes of each } \\
\text { subject to the one } \\
\text { topic }\end{array}$ & $\begin{array}{l}\text { Skills, processes and } \\
\text { concepts of one } \\
\text { discipline help to } \\
\text { develop understanding } \\
\text { about the other one }\end{array}$ & $\begin{array}{l}\text { Innovative solutions of } \\
\text { a real life problem by } \\
\text { developing the content } \\
\text { and tools of different } \\
\text { disciplines }\end{array}$ \\
\hline Aim & $\begin{array}{l}\text { To obtain content } \\
\text { knowledge }\end{array}$ & $\begin{array}{l}\text { To develop learners' } \\
\text { general skills. }\end{array}$ & $\begin{array}{l}\text { To solve a real-life } \\
\text { problem }\end{array}$ \\
\hline
\end{tabular}

\section{Research design}

Methods: The empirical research question is - to investigate, how the future teachers' describe integrated learning in their lesson plans, in order to identify appearance of different kinds of integration.

Data collecting. The study was based on the qualitative analysis ofmaterials from student practice diaries. 10 integrated lesson plans made by $4^{\text {rd }}$ year students of the Pre-school and Primary School Teacher Professional Bachelor's Degree Program of University of Latvia were chosenfor analysis.All these students' performance was highly evaluated by their mentors, so we can trust that their professional competences are on a good level. What differs is a structure and formulations of lesson plan components. The analysis of these differences can give a feedback of professional study process and help to investigate better ways, how to introduce an integrated learning in pre-service teacher professional practice more effectively.

Before study practice, students have got theoretical insight about integrated learning. In accordance with an instruction, all lesson plans should contain:

1) topic/ title; question for learning,

2) aim and objectives,

3) content of learning of several subjects,

4) learning outcomes, 
5) description of a process of lesson and teaching/ learning methods,

6) feedback.

Qualitative analysis of the data was carried out by two experts. Each of them coded the data independently, then results of the analysis were compared, discussed and common conclusions were made.

Lesson plans were read through several times by two experts, marking the separate words and sentences, which could be interpreted to particular approach of integration. Then generalization was undertaken by grouping codes with similar meaning into one category (Mayring, 2007; Saldana, 2012). Then these categories were related to the focus and structure of multidisciplinary, inter-disciplinary and trans-disciplinary integration.

\section{Results}

By analysing the lesson plans, few aspects were revealed as different. They could be interpreted as indicators of the different types of integration. Obviously, there were varieties of the formulation and developmentof a topic,reliability of learning outcomes, logic of connections of separate parts of the lesson and distribution of learners'and teacher roles were analyzed. These categories partly correspond with questions offered by Paxson's for analysis of integrated learning:

1. What is the phenomenological context of this task?

2. What question or aim is being addressed in this problem?

3. What set of conceptual ideas are students expected to engage with in this task?

4. What reasoning strategies are students expected to engage with in this task? (Paxson, 1996).

One difference is related to the formulation of a topic. In some lesson plans topics were formulated in one word, for example, "Winter", "Air", "Electricity", "Capital", as it is traditional in most textbooks and curriculum.

Such briefly and generalized formulation of a topic allows the teacher to choose/ realize freely the learning content of various disciplines. For example, in "Winter" lesson, learners "read and visualize poems about winter (literature), look at reproductions of various works of art, create an illustration of previously read poem (art)." Thereafter, teacher offers to primary students "to analyze images of the problem situations during the winter and the task about safety on the ice (social sciences)". Each task is well done and learners read, imagine, calculate, discuss and acquire new content, but a new set of knowledge is kaleidoscopic, conjunction between learning episodes are formal without holistic or personally meaningful understanding. Fragmented courses are likely to support fragmented understanding (Steinberg, 2003). 
Another aspect, which makes difference in lesson plans, is formulation of learning goals. Such formulations as promoting primary students' "knowledge of the capital's objects by learning the capitalization of letters", "understanding of the geometric figures", "knowledge about electricity", "understanding the depicting of the landscape in the application". They indicate, that pre-service teacher focuses on teaching the content of curriculum subjects. Together with it, a topic itself becomes unimportant - it looks as just a pretext for "talking about" something familiar rather than for understanding the regularities of the real life (such combination of words appears often in the descriptions of a lesson flow: "what was a poem about?", "write three sentences about...!", "what do you know/ think about...? etc.).

If the meaning of learning from the pupil's perspective is ignored in the lesson plan, the transmission of subject knowledge and skills risks to become formal; the integration of the various disciplines across the topic - mechanical; the student's involvement in learning activities as an active participant insignificantly.

All mentioned indicate, that difficulties in providing a logical and natural connection between the content of different subjects and the purpose of the lesson and have aroused.

Another type of lesson plans contains different way of defining the topic and learning goals. Such titles of a lesson as "Why living organisms need clean air?", "How can I handle the electrical equipment safely?", "How can we support the famous Latvian basketball player in USA?", "How can I depict the beauty of winter in different forms of art?" demonstrates some inner connections between the objects from different disciplines.

Cognitive question helps the teacher to recognize the disciplines involved and justify the thinking strategies needed for resolving the question. These lesson plans confirms a high level of pre-service teachers' competence to organize the learning process in classroom. For example, in lesson plan "How can I create a book?" a variety of learners' activities together with appropriate choice of the content of curriculum subjects were described. There learners are expected to set criteria for qualitative book, create the texts/ stories (literature and native language) and illustrations (art), classify the professions necessary for publishing the book and distribute the roles in groups appropriately (social sciences), evaluate individual abilities and interests (all disciplines together).

The lesson is perfectly composed; teacher leads the primary students' learning by using the integration of learning content several disciplines for developing general skills, introducing different thinking strategies and teaching methods.

Cautious is that the main purpose of learners' activities planned by teacher to create a book, is accepted without a debate about why this book is needed. The 
absence of space for learners' voice/ ideas/ real life experience and the actual socio-cultural context do not provide an awareness of the significance of learning. This type of lesson fits with the characterization of inter-disciplinary learning, leaving open a question about the development of learners' life-skills and transformative learning.

There were two lesson plans which differ much from other with a formulation of a topic and introducing it. In both cases pre-service teachers begin the lesson with problematic situation that needs to be resolved somehow - "The teacher's dog went missing yesterday; please help to find him!" and "A classmate is accused painfully in social network; what should she do now?". Pre-service teachers admitted there, that these problems were not planned previously, but encountered in real life. So, lesson plans are written after activities; they are rather documentary than a plan.

The pupils' activity was suggested by the personal significance of the situation; the joint decision about the most constructive solution to the problem setting justified the meaning of the activities and made a clear progress towards the result to be achieved. In theory, this is described as an authentic problem situation, which involves counting on the complexity of life, inconsistency, ambiguity, unpredictability (Lenkauskaite, 2015).

Student describe, how the learners analyze the possible causes of the situation from different perspectives, offer ideas for problem solving, make the decision to work out an apology email/ announcement about a missing dog in groups in order to resolve misunderstandings/find a dog, create a draft and discuss the possibilities to deliver it properly, set criteria for the successful outcomes of a case and discuss a further sceneries. In feedback, personally and social significance of learning the content of different disciplines were identified. Learners analyzed how media studies (distribution of the announcement, safety on the Web), ethics (conflict resolution, compassion, and responsibility), language (applied writing) and social sciences (organization of cooperative activities) can help to solve real-life situations.

Characterictics of lesson plan components that helps to identify approaches of integrated learning are summarized in Table 2.

These lesson plans can be interpreted as the realization of transdisciplinary learning, as a topic of lesson is related to an actual real-life situation, the concepts and processes of several curriculum subjects are adapted to logically structured problem solving steps, and learners have a possibility to join their life experiences and realize the choices in each learning situation. In her reflection, student had written her conclusions: "Real life appears as the best counselor which helps to realize the integrated lesson purposefully and meaningfully. There is nothing artificial to imagine. The need to solve the real life situation motivated children. 
The specific tasks aroused by themselves. Children understand the importance of each learning activity for solving the problem. I was not scared of real life!"

Table 2 Characteristics of different approaches to integrated curriculum

\begin{tabular}{|l|l|l|l|}
\hline Integration & Multidisciplinary & Inter-disciplinary & Transdisciplinary \\
\hline $\begin{array}{l}\text { Introductionof } \\
\text { a topic }\end{array}$ & $\begin{array}{l}\text { Introducing the topic } \\
\text { in one word: our } \\
\text { topic is... }\end{array}$ & $\begin{array}{l}\text { Introducing a } \\
\text { cognitive question: } \\
\text { how to depict a } \\
\text { winter beauty? }\end{array}$ & $\begin{array}{l}\text { Dicsussing the real-life } \\
\text { problem setting: Please, } \\
\text { help me to find my dog! }\end{array}$ \\
\hline Learning goals & $\begin{array}{l}\text { To learn discipline } \\
\text { content: to complete } \\
\text { goodness. }\end{array}$ & $\begin{array}{l}\text { To promote } \\
\text { development of } \\
\text { general skills: to } \\
\text { complete the } \\
\text { analytical thinking } \\
\text { and creativity by } \\
\text { producing a book. }\end{array}$ & $\begin{array}{l}\text { To complete life-skills: } \\
\text { to promote a } \\
\text { development of social } \\
\text { responsibility, by } \\
\text { engaging in a charity } \\
\text { campaign. }\end{array}$ \\
\hline Content & Defined by Standard & $\begin{array}{l}\text { Defined by standard, } \\
\text { adapted by teachers }\end{array}$ & $\begin{array}{l}\text { Chosen by learners, } \\
\text { adapted to standards by } \\
\text { teachers. }\end{array}$ \\
\hline
\end{tabular}

This finding, together with elation and joy, reveals one more aspect of transdisciplinary learning. A word "fear", used by student there, denotes the challenge for teacher's competence and teachers' educators - how to react professionally to various events in the everyday life of pupils and to show the learners that learning is possible in any situation of life.

\section{Conclusion and Discussion}

Following features of transdisciplinary learning were classified by content analysis:

- $\quad$ Problem is based on a specific life event. Setting the cognitive question does not automatically lead to transdisciplinary learning.

- All activities are not planned previously, the openness to the concrete situation and learners' ideas are crucially important for transdisciplinary learning.

- Teacher can provide such process of learning, if he understand a structure and meaning in real life context.

In order to help pre-service teachers understand TD training in study process, it makes sense to:

- Introduce the experiments with a situated learning to provide students' own experience how the situation can serve as a transdisciplinary learning opportunity. 
- To organize a cooperation of members of teaching staff for practice the trans-disciplinary learning in professional studies.

- Together with specific professional competences, cultivate pre-service teacher's deep learning, responsiveness, flexibility, creativity, decisionmaking skills.

In accordance with traditionally implemented principle of 40 minutes lesson and the assumption that integrated learning is possible only for an experienced teacher, instruction, students have an instruction to developed each integrated lesson plan as an autonomous thematic unit for 80 minutes. It is possible that the time limit and several unrelated integrated models (i.e., rectangles in environment and Christmas traditions and safety on an ice) in one day interferes the meaningful resolution of a life-related problem. An integrated model practice is recommended for a longer period of time - day or week.

In study process, to develop pre-service teachers' awareness of a paradox that more complex learning can appear easier than simple one, if it has a holistic nature.

\section{References}

Anspoka, Z. (2003). Veseluma metode lasītmācībā un rakstītmācībāa. Latviešu valoda 1. klasei. Skolotäja grāmata. Rīga: Lielvārds.

Boix-Mansilla, V. (2010). Learning to Synthesize: the Development of Interdisciplinary Understanding. In: R.Frodeman, J. Thomson-Klein, C. Mitcham \& J. B. Holbrook (Eds.) The Oxford Handbook of Interdisciplinary (pp. 288 - 306). Oxford University Press, Oxford.

Csorba, C. (2013). Design and Delivery of a Training Program for Teachers in Primary Education: Interdisciplinary Organization for Key Competences Training for Young Schoolchildren, from Pre-school Class to Class IV. Procedia - Social and Behavioral Sciences, 76, 285-290.

Drake, S. M., \& Burns, R. C. (2004). Meeting Standards Through Integrated Curriculum. Retrieved from http://www.ascd.org/portal/site/ascd/template.chapter/menuitem.b71d 101a2f7c208cdeb3ffdb62108a0c/?chapterMgmtId=9ae9cba5ddcaff00VgnVCM100000 3d01a8c0RCRD

Dēkens, K. (1919). Rokasgrāmata pedagogijīa. Rīga: Kultūras balss.

Hatano, G., \& Inagaki, K. (1986). Two courses of expertise. In H. Stevenson, H. Azuma, \& K. Hakuta (Eds.), Children development and education in Japan (pp. 262-272). New York: Freeman.

Hattie, J. (2009). Visible learning: a synthesis of meta-analysis relating to achievment. Routledge, Oxon.

Helmane, I., \& Briska, I. (2017). What is Developing Integrated or Interdisciplinary or Multidisciplinary or Transdisciplinary Education in School? SIGNUM TEMPORIS, 9 (1), 7-15. Retrieved from https://www.degruyter.com/view/j/sigtem.2017.9.issue-1/sigtem2017-0010/sigtem-2017-0010.xml

Kaufman, D., Moss, D. M., \& Osborn, T. A. (2003). Beyond the Bondaries: A Transdisciplinary Approach to Learning and Teaching. Praeger. Westport, CT. 
Kauliņa, A. (2013). Integratīva mācību metodika sākumskolēnu specifisku lasīšanas traucējumu mazināšanai. Promocijasdarbs. Rīga: RPIVA.

Kidron, A., \& Kali, Y. (2015). Boundary Breaking for Interdisciplinary Learnig. Research in Learning Technology, [S.I.] v. 23. oct. 2015. Retrieved from https://journal.alt.ac.uk/index.php/rlt/article/view/1646/1996

Kramer, P., Ideishi, R. I., Kearney, P. J., Cohen, M. E., Ames, J. O., Shea, G. B., Schemm, R., \& Blumberg, P. (2007). Achieving curricular themes through learner-centered teaching.Occupational Therapy in Health Care, 21 (1/2), 185-198.

Lenkauskaite, J. (2015). Promoting Student's Creativity by Identification of Problem. In: Creativity is Everywhere. Exercises for Promoting Creativity for Teachers and Parents. Riga: RaKa, 18.-20.

Mayring, P. (2007). On Generalization in Qualitatively Oriented Research. Forum Qualitative Sozialforschung / Forum: Qualitative social research, 8 (3), Art. 26. Retrieved from http://www.qualitative-research.net/index.phb/fqs/article/viewArticle/291/641

Mutton, T., Hagger, H., \& Burn, K. (2011). Learning to plan, planning to learn: the developing expertise of beginning teachers. Teachers and Teaching. 17 (4), 399-416.

Paxson, T. D.(1996). Modes of Interaction Between Disciplines. Journal of Education., 45 (2): 79-95.

Petere, A.(2014). Studentu gatavība mācību procesā īstenot integrētu atklājumamācību modeli jaunākā skolas vecuma bērniem. Teorija praksei mūsdienu sabiedrības izglītīb $\bar{a}$, konferences rakstukrājums. Rīga: RPIVA.

Pētersons, Ē. (1931). Vispārīgā didaktika. Rīga: A. Gulbis.

Saldana, J. (2012). The Coding Manual for Qualitative Researchers, 2 edition. London: SAGE Publications Ltd.

Savage, J. (2010). Cross-curricular Teaching and Learning 5: Definations. Retrieved from http://www.jsavage.org.uk/research/cross-curricular-teaching-and-learning-5definitions/

Steinberg, A. (1997). Real Learning, Real Work. New York: Routledge.

Sterling, S. (2010). Transformative learning and sustainability: sketching the conceptual ground, Learning and Teaching in Higher Education, Issue 5, 2010 -11, 17-33. 